\title{
Tinjauan Kondisi Fisik Perairan Teluk Bandara DEO Kota Sorong
}

\author{
H. Pristianto ${ }^{1)}$ dan A. Rusdi ${ }^{2)}$ \\ ${ }^{1,2)}$ Program Studi Teknik Sipil Universitas Muhammadiyah Sorong \\ Jl. Pendidikan No 27, Kota Sorong 98400 \\ Email : tekniksipilsorong@gmail.com
}

\begin{abstract}
Abstrak
Teluk Bandara Dominique Edward Osok (DEO) Kota Sorong memiliki suatu peran dan fungsi yang sangat strategis, di antaranya sebagai penopang perkembangan perekonomian dan fungsi lingkungan terutama bagi wilayah Kota dan Kabupaten Sorong. Tujuan penelitian ini adalah untuk mengidentifikasi permasalahan fisik yang terjadi dan sebagai referensi awal untuk menyusun studi kelayakan yang lebih komprehensif terhadap rencana pengembangan wilayah perairan Teluk Bandara DEO Kota Sorong. Tahapan penelitian adalah 1).Mengidentifikasi muara-muara sungai yang mempengaruhi kondisi perairan lokasi studi; 2).Mengumpulkan data topografi, hidrometri dan data kualitas air daerah aliran sungai yang bermuara di lokasi studi 3).Melakukan analisa kondisi topografi dan hidrometri daerah aliran sungai yang bermuara di lokasi studi; 4).Mengidentifikasi kondisi wilayah pesisir di sepanjang pantai lokasi studi; dan 5).Mengidentifikasi permasalah fisik yang terjadi di lokasi studi.

Hasil laboratorium kualitas air dari beberapa titik sampel di daerah aliran sungai yang bermuara di Teluk DEO menunjukkan nilai yang cukup besar bila dibandingkan dengan mutu baku yang di tetapkan dalam PP No. 82/2001, terutama di daerah hilir sungai yaitu masuk dalam kualitas air kelas 4 (air untuk mengairi tanaman). Dan saat ini juga terjadi kurang terkontrolnya kegiatan penebangan vegetasi mangrove di sepanjang pantai lokasi studi. Secara fisik terlihat bahwa kondisi perairan muara di sepanjang Teluk DEO tersebut relatif keruh yang mengindikasikan relatif tingginya sedimentasi/pendangkalan pada lokasi tersebut. Apabila pendangkalan semakin tidak terkendali, maka dikhawatirkan akan: 1).Menggangu aktifitas transportasi laut di muara sungai; 2).Menyebabkan banjir di bagian hulu dari muara yang merupakan kawasan pemukiman padat penduduk; 3).Menggangu ekosistem lingkungan perairan di teluk Bandara DEO Kota Sorong.
\end{abstract}

Kata Kunci : Daerah aliran sungai, Sedimentasi, Teluk DEO Sorong

\section{Pendahuluan}

Teluk Bandara Dominique Edward Osok (DEO) Kota Sorong memiliki suatu peran dan fungsi yang sangat strategis, di antaranya sebagai penopang perkembangan perekonomian dan fungsi ekologis (lingkungan) terutama bagi wilayah Kota Sorong dan Kabupaten Sorong. Dari foto udara terlihat bahwa kondisi teluk tersebut relatif keruh yang mengindikasikan relatif tingginya sedimentasi /pendangkalan pada lokasi tersebut. Di wilayah teluk tersebut bermuara beberapa sungai, yang salah satunya adalah muara Sungai Remu, yang mana sampai saat ini merupakan salah satu media transportasi laut dimana kapal-kapal masyarakat maupun nelayan keluar masuk. Apabila pendangkalan semakin tidak terkendali, maka dikhawatirkan akan : 1).Menggangu aktifitas transportasi laut di muara sungai; 2).Menyebabkan banjir di bagian hulu dari muara yang merupakan kawasan pemukiman padat penduduk; 3).Menggangu ekosistem lingkungan perairan di teluk Bandara DEO Kota Sorong. Tujuan penelitian adalah untuk mengidentifikasi permasalahan fisik yang terjadi di perairan teluk Bandara DEO Kota Sorong. Adapun manfaatnya adalah sebagai referensi awal untuk menyusun studi kelayakan yang lebih komprehensif terhadap rencana pengembangan wilayah perairan Teluk Bandara DEO Kota Sorong. 


\section{Metodologi}

Tahapan penelitian yang digunakan adalah sebagai berikut :

1. Mengidentifikasi muara-muara sungai yang mempengaruhi kondisi perairan di Teluk Bandara DEO Kota Sorong

2. Mengumpulkan data topografi dan hidrometri daerah aliran sungai yang bermuara di perairan Teluk Bandara DEO Kota Sorong

3. Melakukan analisa kondisi topografi dan hidrometri daerah aliran sungai yang bermuara di perairan Teluk Bandara DEO Kota Sorong.

4. Mengidentifikasi kondisi wilayah pesisir pantai di sepanjang teluk Bandara DEO Kota Sorong.

5. Mengidentifikasi permasalah fisik yang terjadi di perairan Teluk Bandara DEO Kota Sorong.

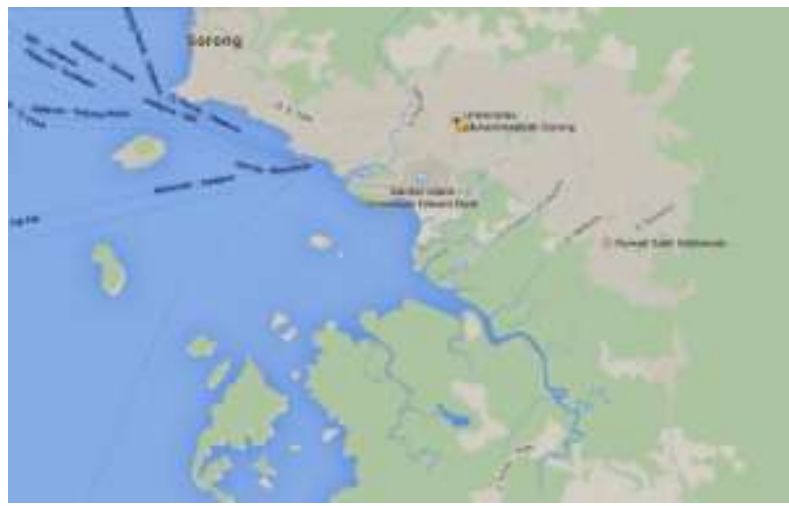

Gambar 1. Lokasi Studi

\section{Hasil Dan Pembahasan}

\section{Kondisi Muara Sungai yang Mempengaruhi Kondisi Perairan Teluk Bandara DEO}

Teluk Bandara Dominique Edward Osok (DEO) Kota Sorong memiliki suatu peran dan fungsi yang sangat strategis, di antaranya sebagai penopang perkembangan perekonomian dan fungsi ekologis (lingkungan) terutama bagi wilayah Kota Sorong dan Kabupaten Sorong. Apabila memperhatikan kondisi dari foto udara yang ada, pada teluk tersebut bermuara kurang lebih enam sungai yang ada di wilayah kota dan kabupaten Sorong, yaitu :

a. Muara Sungai Remu Kota Sorong (berada di sebelah barat ujung run way Bandara DEO Kota Sorong);

b. Muara muara Sungai dari Malanu KM 8 Kota Sorong (berada di sebelah timur ujung runway Bandara DEO Kota Sorong);

c. Muara Sungai Klagison Kota Sorong (dari wilayah KM 10 dan 12 Kota Sorong);

d. Muara Sungai belakang RS Sele Besolu Kota Sorong;

e. Muara Sungai Wermon (dari arah belakang Polres Kabupaten Sorong); dan

f. Muara Sungai Klafma (dari arah Kantor Bupati KM 24 Kabupaten Sorong). 


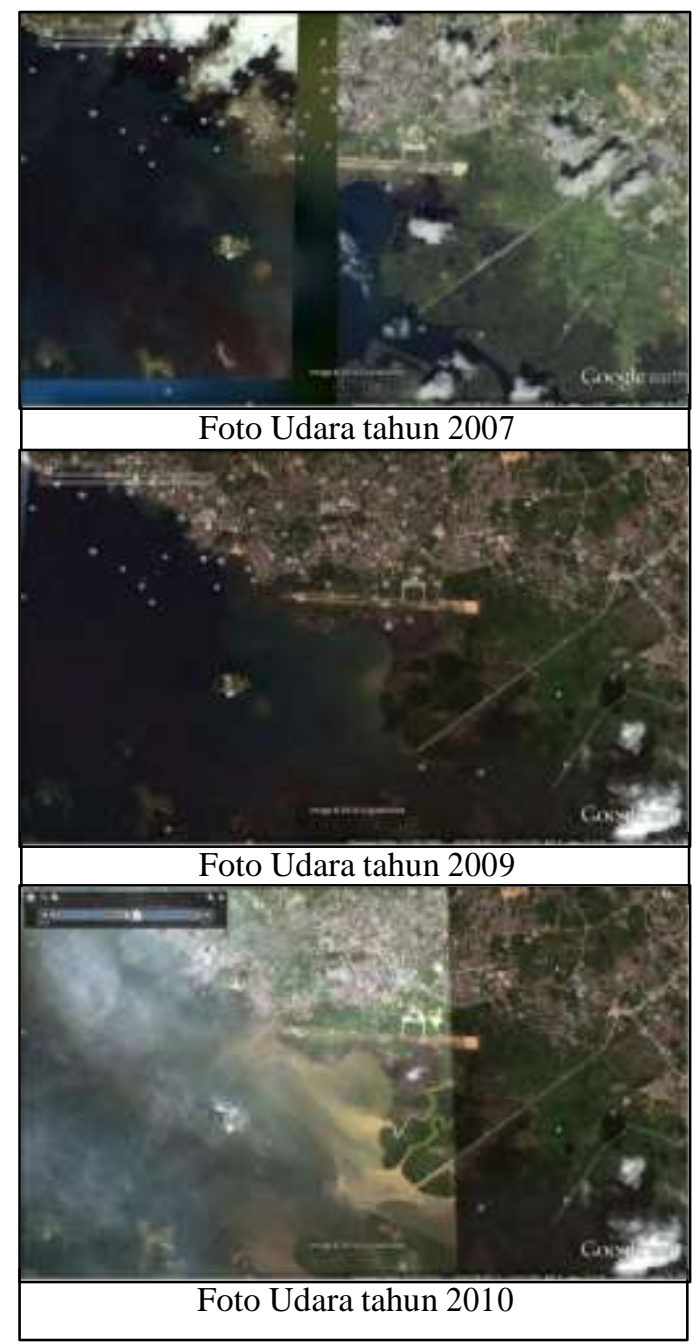

Gambar 2. Perbandingan Kondisi Fisik tahun 2007-2009-2010

\section{Analisa Kondisi Hidrometri Daerah Aliran Sungai}

Dari analisa kondisi daerah aliran sungai yang bermuara di wilayah Teluk DEO Kota Sorong, didapatkan kondisi bahwa :

1. Pola aliran sungainya adalah Dendritik, yaitu pola aliran sungai pada daerah dengan batuan sejenis yang penyebarannya luas, serta ditutupi oleh endapan sedimen yang luas dan terletak di daerah datar.

2. Indeks Kerapatan Sungai termasuk kategori sedang, yang dapat diperkirakan bahwa sungaisungai tersebut mempunyai gejala aliran sebagai berikut :

a. Alur sungai melewati batuan dengan resistensi relatif keras, sehingga angkutan sedimen akibat erosi dasar sungai yang berproses secara alamiah alamiah relatif kecil

b. Alur sungai melewati batuan yang tidak kedap air, sehingga air hujan yang jatuh pada DAS tersebut secara alamiah relatif kecil yang menjadi aliran permukaan.

Adapun fakta bahwa banjir masih menjadi persoalan di wilayah DAS sekitar Teluk DEO lebih disebabkan pada pendangkalan sungai akibat sendapan sedimen dari proses galian $\mathrm{C} \mathrm{di}$ sekitar aliran sungai. Jadi bukan karena karakteristik sungainya. 
Secara umum, ketersediaan data dan peralatan untuk mendapatkan data hidrometri DAS Remu sangat kurang, karena fakta dilapangan menyebutkan bahwa :

1. Tidak ada pos duga air untuk pengukuran debit sungai di sepanjang DAS Remu

2. Instansi terkait khususnya Dinas Pekerjaan Umum Kota Sorong tidak mempunyai peralatan pengukur tingkat sedimentasi DAS Remu

3. Hanya terdapat satu stasiun pencatat curah hujan di DAS Remu yaitu berada di Bandara DEO Kota Sorong, tepatnya pada bagian muara sungai Remu, dan baru mulai beroperasi pada tahun 2007.

\section{Kondisi Pesisir Pantai di Sepanjang Wilayah Teluk Bandara DEO.}

Analisa Data Angin untuk Peramalan Gelombang

Tasmin (2011) melakukan peramalan gelombang yang kemungkinan terjadi di sepanjang garis pantai wilayah Kota Sorong. Data yang dipakai adalah data angin yang diperoleh berasal dari Pos Pengamatan BMKG Bandara DEO Sorong yaitu data kecepatan dan arah angin jam-jaman selama 3 tahun yaitu dari tahun 2008, 2009, dan 2010.

Dari analisa dapat disimpulkan bahwa kejadian gelombang dari tahun 2008 sampai 2010 menunjukkan bahwa kondisi tidak bergelombang lebih dominan yaitu 81,59\% dan kondisi gelombang yang dominan pada arah Barat yaitu sebesar 8,28\% dan Barat Daya yaitu 5,97\%. Hasil tersebut dapat disajikan dalam bentuk diagram untuk mengetahui karakteristik gelombang yaitu dengan diagram gelombang dengan interval $0,2 \mathrm{~m}$ seperti yang terlihat pada gambar disamping.

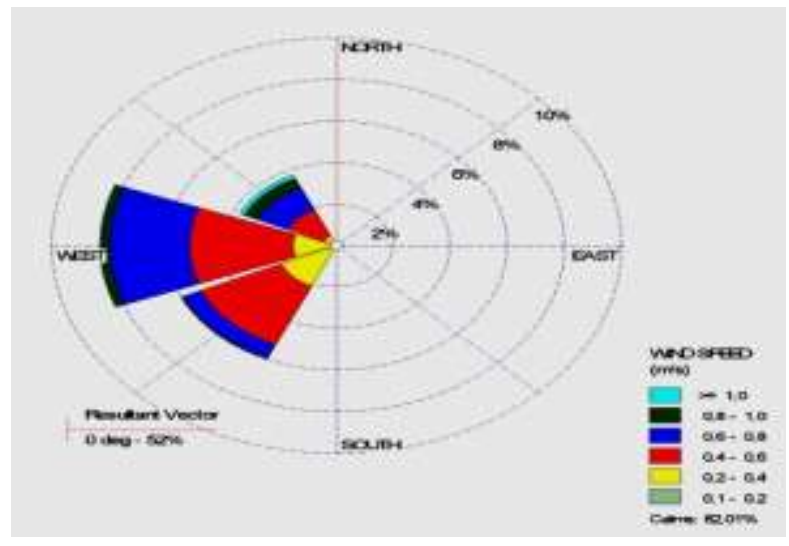

Gambar 3. Mawar Gelombang 2008-2010

\section{Permasalahan Fisik Perairan Teluk Bandara DEO}

\section{Kondisi Kebisingan}

Rachman (2013) melakukan penelitian tentang bagaimana tingkat kebisingan wilayah di sekitar bandara DEO. Penelitian dilakukan di 3 (tiga) titik sebagaimana terlihat pada gambar 4 disamping. Berdasarkan hasil ketentuan sesuai dengan baku mutu tingkat kebisingan ketentuan Menteri Negara Lingkungan Hidup Nomor KEP.48/MENLH/11/1996, tanggal 25 Nopember 1996 maka :

1. untuk daerah-daerah pemukiman seperti di Titik (A1) Ujung Landas Pacu Bagian Barat $(75,8$ dBA), dan A3 Ujung Landas Pacu Bagian Timur ( $84.7 \mathrm{dBA}$ ) di atas ambang baku mutu (55 dBA).

2. Sedangkan lokasi Fasilitas Umum seperti Lokasi Terminal Bandara atau titik A2 (75,9 dBA) dinyatakan di atas ambang baku mutu (60 dBA). 


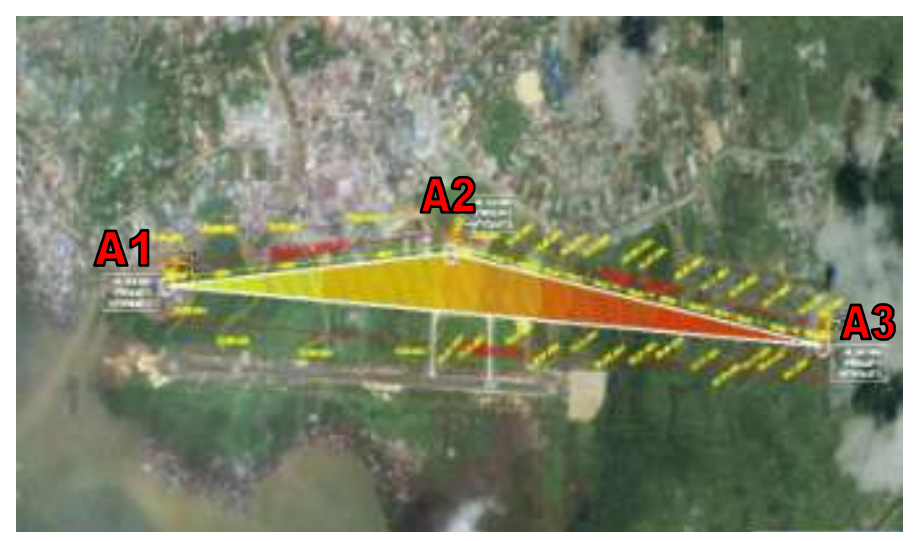

Gambar 4. Peta Kebisingan sekitar wilayah Teluk DEO

\section{Pencemaran Sungai}

Malawat (2009) melakukan penelitian untuk mengidentifikasi bagaimana kualitas air pada muara sungai Remu yang alirannya masuk ke wilayah Teluk DEO,dan hasilnya adalah besarnya konsentrasi DHL diatas 19,900 $\mu \mathrm{s} ;$ TDS $=27,200 \mathrm{mg} / \mathrm{l} ; \mathrm{TSS}=55,8 \mathrm{mg} / \mathrm{l} ; \mathrm{pH}=7,18 \mathrm{mg} / \mathrm{l} ; \mathrm{DO}=7,48 \mathrm{mg} / \mathrm{l} ; \mathrm{BOD}$ $=12 \mathrm{mg} / \mathrm{l} ; \mathrm{COD}=145 \mathrm{mg} / \mathrm{l} ;$ Sulfat $=12 \mathrm{mg} / \mathrm{l} ;$ Klorida $=289,2 \mathrm{mg} / \mathrm{l} ;$ Seng $=0,267 \mathrm{mg} / \mathrm{l} ;$ Besi $=0,136$ $\mathrm{mg} / \mathrm{l}$; Tembaga $=0,042 \mathrm{mg} / \mathrm{l}$; dan Minyak dan Lemak 35,41 mg/l. Hasil laboratorium tersebut cukup besar bila dibandingkan dengan mutu baku yang di tetapkan dalam peraturan pemerintah No. 82 Tahun 2001, sehingga dari kualitas air Sungai Remu masuk dalam kualitas air kelas 4 (air untuk mengairi petanaman).

\section{Analisa Angkutan Antar Pulau Melalui Muara}

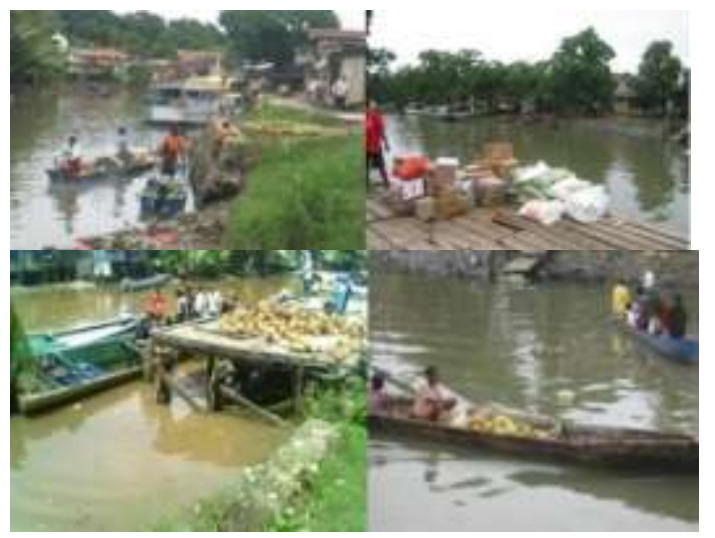

Gambar 5. Aktivitas Masyarakat di muara

Matdoan (2011) melakukan penelitian mengenai kondisi Muara Sungai Remu dalam menunjang kelancaran angkutan antar pulau di Kota Sorong. Kesimpulan yang dapat diambil yaitu :

1. lebar muara sungai remu sudah cukup menunjang bagi kapal-kapal yang keluar dan masuk, akan tetapi masyarakat sangat terganggu karena masih banyak kapal-kapal yang parkir pada sepanjang aliran sungai menuju hulu (dermaga) dan masih banyaknya sampah disepanjang aliran Sungai Remu.

2. Selama peninjauan langsung di lapangan rata-rata angkutan yang masuk adalah sebanyak 56 angkutan/hari dan angkutan yang keluar sebanyak 51 angkutan/hari. Beberapa hari sebelum perayaan natal masyarakat yang datang dari pulau sangat banyak, hal ini karena mereka harus mempersiapkan perlengkapan untuk menyambut hari raya natal. 


\section{Pendangkalan di Muara dan sepanjang pesisir pantai Teluk DEO}

Dari foto udara terlihat bahwa kondisi air ke enam muara sungai tersebut relatif keruh yang mengindikasikan relatif tingginya proses sedimentasi. Dan sekilas yang paling parah adalah dari 2 muara sungai di belakang bandara DEO yang merupakan sungai dari arah kampung Malanu. Daerah itu kita kenal sebagai salah satu pusat galian C di Kota Sorong. Hal ini tidak terlepas dari kontribusi erosi tanah yang berasal dari bagian kawasan hulu dari sungai yang lahannya sudah terbuka akibat kegiatan galian pasir tersebut. Kondisi semua itu ditambah dengan komulatif sampah yang tertumpuk di muara menyebabkan proses pendangkalan yang jika tidak segera diatasi akan menyebabkan masalah nantinya dibagian hulu. Muara yang dangkal akan menyebabkan terhambatnya kelancaran air dari sungai menuju laut, sehingga daerah pemukiman di sekitarnya akan rawan tergenang. Gambar disamping sedikit member ilustrasi kondisi pendangkalan di bagian muara sungai di sekitar wilayah Teluk DEO Kota Sorong

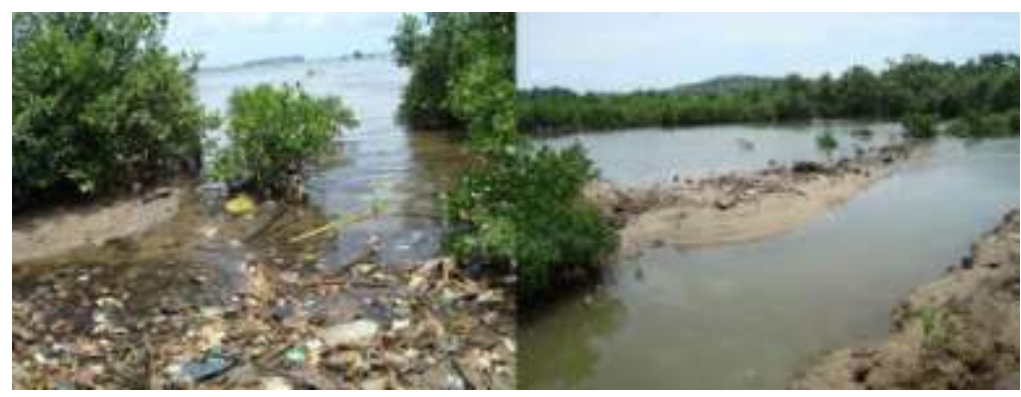

Gambar 6. Visualisasi pendangkalan di Muara

\section{Pendangkalan Teluk Bandara DEO Kota Sorong}

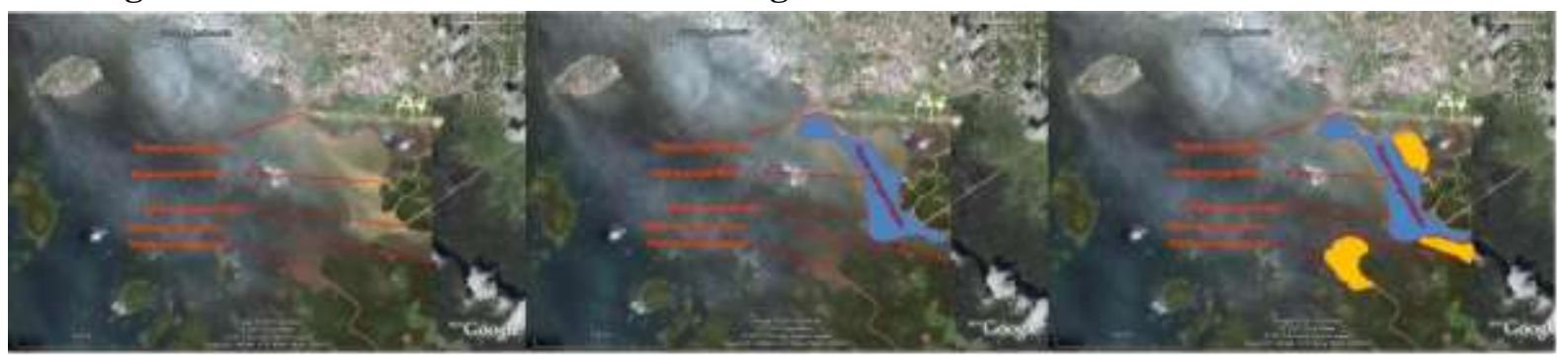

(1)

(2)

Gambar 7. Asumsi Pola pendangkalan di Teluk Bandara DEO
(3)

Pendangkalan yang terjadi di muara ke enam sungai di sekitar wilayah Teluk Bandara DEO menguatkan kekhawatiran akan proses lanjutannya dan pengaruhnya terhadap kondisi teluk itu sendiri. Pada gambar di atas, peneliti berasumsi bahwa lambat laun pola pendangkalan di teluk Bandara DEO sangat dimungkinkan. Pada gambar 7 (nomer 2 yaitu arsiran warna biru) terlihat pola awal pendangkalan berdasarkan visualisasi dari foto udara pada tahun 2010. Dan dikhawatirkan pola lanjutannya yaitu arsiran warna kuning, yang mana pendangkalan penuh pada teluk DEO yang diawali dari penutupan ke enam muara sungai yang ada di dalamnya. Apabila pendangkalan semakin tidak terkendali, maka dikhawatirkan akan:

1. Menggangu aktifitas transportasi laut di muara sungai;

2. Menyebabkan banjir di bagian hulu dari muara yang merupakan kawasan pemukiman padat penduduk;

3. Menggangu ekosistem lingkungan perairan di teluk Bandara DEO Kota Sorong. 


\section{Kesimpulan}

Kesimpulan yang dapat diambil adalah telah teridentifikasinya beberapa p:

a. Berdasarkan hasil ketentuan sesuai dengan baku mutu tingkat kebisingan ketentuan Menteri Negara Lingkungan Hidup Nomor KEP.48/MENLH/11/1996, tanggal 25 Nopember 1996 maka untuk daerah-daerah pemukiman seperti di Titik (A1) Ujung Landas Pacu Bagian Barat (75,8 dBA),dan A3 Ujung Landas Pacu Bagian Timur (84.7 dBA) di atas ambang baku mutu (55 dBA); sedangkan lokasi Fasilitas Umum seperti Lokasi Terminal Bandara atau titik A2 (75,9 dBA) dinyatakan di atas ambang baku mutu (60 dBA).

b. Hasil laboratorium terhadap sampel air dari muara Sungai Remu yang bermuara di perairan Teluk Bandara DEO Kota Sorong tersebut cukup besar bila dibandingkan dengan mutu baku yang di tetapkan dalam peraturan pemerintah No. 82 Tahun 2001, sehingga dari kualitas air Sungai Remu masuk dalam kualitas air kelas 4 (air untuk mengairi petanaman).

c. Lebar muara sungai remu sudah cukup menunjang bagi kapal-kapal yang keluar dan masuk, akan tetapi masyarakat sangat terganggu karena masih banyak kapal-kapal yang parkir pada sepanjang aliran sungai menuju hulu (dermaga) dan masih banyaknya sampah disepanjang aliran Sungai Remu.

d. Pendangkalan di wilayah muara terjadi tidak terlepas dari kontribusi erosi tanah yang berasal dari bagian kawasan hulu dari sungai yang lahannya sudah terbuka akibat kegiatan galian pasir tersebut. Kondisi semua itu ditambah dengan komulatif sampah yang tertumpuk di muara menyebabkan proses pendangkalan yang jika tidak segera diatasi akan menyebabkan masalah nantinya dibagian hulu. Muara yang dangkal akan menyebabkan terhambatnya kelancaran air dari sungai menuju laut, sehingga daerah pemukiman di sekitarnya akan rawan tergenang.

e. Pendangkalan yang terjadi di muara ke enam sungai di sekitar wilayah Teluk Bandara DEO menguatkan kekhawatiran akan proses lanjutannya dan pengaruhnya terhadap kondisi teluk itu sendiri

\section{Daftar Pustaka}

Maryono (2005). Eko-Hidraulik Pembangunan Sungai, Magister Sistem Teknik PPS Universitas Gadjah Mada Yogyakarta.

Malawat (2009). Dampak Aktifitas Masyarakat Kota Sorong Terhadap Tingkat Pencemaran Air Sungai Remu, Fakultas Teknik Universitas Muhammadiyah Sorong.

Matdoan (2011). Tinjauan Kondisi Muara Sungai Remu Dalam Menunjang Kelancaran Angkutan Antar Pulau du Wilayah Sorong, Jurnal Median LPPM Universitas Al-Amin Muhammadiyah Sorong, volume III no 1, 162-171

Rachman (2013). Analisa Kebisingan Lalu Lintas Udara di Sekitar Bandara Udara DEO Kota Sorong, Fakultas Teknik Universitas Muhammadiyah Sorong.

Soewarno (1991). Hidrologi Pengukuran dan Pengolahan Data Aliran Sungai, Nova. Bandung. Sosrodarsono, S dan Takeda, K. (1999). Hidrologi untuk Pengairan, PT Pradnya Paramita. Jakarta.

Suripin (2004). Sistem Drainase Perkotaan Yang Berkelanjutan, Penerbit Andi, Yogyakarta.

Tasmin (2011). Tinjauan Stabilitas Tanggul Penahan Gelombang Pada Pantai Dofior Kota Sorong, Jurnal Median LPPM Universitas Al-Amin Muhammadiyah Sorong, volume III no 1, 172181 
